УДК 004.493

\author{
Володимир Іванович Руденко \\ Михайло Олександрович Зінченко \\ Наталя Сергївна Грииина \\ Віктор Анатолійович Ченченко
}

Військовий інститут телекомунікацій та інформатизації ім. Героӥв Крут, Киӥв, Украӥна

\title{
ЗАСТОСУВАННЯ В МУЛЬТИАГЕНТНІЙ СИСТЕМІ УПРАВЛІННЯ МОДЕЛІ ФУНКЦІОНУВАННЯ ФРАГМЕНТУ ТЕЛЕКОМУНІКАЦІЙНОЇ МЕРЕЖІ СИСТЕМИ ЗВ'ЯЗКУ ЗБРОЙНИХ СИЛ УКРАЇНИ
}

На сьогоднішній день існує безліч стандартів, де описані архітектура і механізми контролю та управління елементами мережі Carrier Ethernet, але не існує єдиної методики та не сформовані вимоги до системи управління такою мережею зв'язку. В даній статті запропоновано вирішення иьього завдання иляхом моделювання прочесу функціонування телекомунікаційної мережі на основі технології Carrier Ethernet для управління ї̈ конфігурацією. Для створення даної моделі обраний апарат імітаційного моделювання AnyLogic. Метою роботи є виявлення залежності між показниками надійності функціонування телекомунікаційної мережі на основі технологї Carrier Ethernet $і$ процесом функиіонування підсистем управління і відновлення телекомунікаційної мережі. А також отримання залежності коефіиієнту готовності від тривалості часу напрацювання на відмову, часу відновлення відмови та від кількісних характеристик конфігурації модельованого фрагмента мережі. Мультиагентна система, яка є частиною керуючої системи, знаходиться у взаємодї з нею. Використання в мультиагентній системи управління розподіленого об'єкту управління телекомунікаційної мережі на основі технології Carrier Ethernet дозволить отримати демонстрацію динаміки зміни стану фрагмента телекомунікаційної мережі та отримати оцінку мережевої надійності. Рішення завдання з побудови моделі мультиагентної системи управління грунтується на використанні методу агентного моделювання, який відноситься до класу агент-орієнтованих моделей. В роботі використовуються положення теорії ймовірностей, теорії управління $i$ теорії систем. Новизна представленої моделі полягає у виборі нового об'єкта управління Carrier Ethernet, виборі оригінального комплексу механізмів контролю і управління для їх включення в модель, застосуванні математичного апарату агентного моделювання. Використання представленої моделі для дослідження функиіонування телекомунікаційної мережі дозволяє простежувати динаміку поведінки кожного вузла $і$ кожного маршруту зі своїми значеннями інтенсивності відмов і відновлення для структури мережі будь-якої складності, дозволяе вирішувати завдання, пов'язані з визначенням тривалості часу до втрати зв'язності в маршруті і тривалості часу напрацювання на відмову всіх маршрутів одночасно, дозволяє формувати оиінку мережевої надійності та відмовостійкості.

Ключові слова: телекомунікаиійна мережа зв'язку; Carrier Ethernet; агентне моделювання; AnyLogic; механізми ОАM; система управління; мережева надійність.

\section{Вступ}

Постановка проблеми. 3 розвитком телекомунікаційних технологій швидкими темпами розвивається і система зв'язку Збройних сил України, впроваджуються перспективні апаратно-програмні засоби різного призначення (комутатори, маршрутизатори, мультиплексори i т.п.), які базуються на передових телекомунікаційних технологіях. В модернізованих системах зв'язку розширюється номенклатура послуг, що надається, суттєво збільшується обсяг мережевого навантаження, ускладнюються структура, топологія та архітектура телекомунікаційних мереж (ТМ).

Із збільшенням складності ТМ актуалізуються питання дослідження i моделювання систем управління (СУ) відповідними мережами зв'язку[1-5]. В роботах [6-8] висвітлюються питання надійності і стійкості мереж зв'язку. Представлена робота відрізняється від зазначених включенням в модель як об'єкт управління фрагмент ТМ 3С України, а також побудовою СУ на основі апарату агентного моделювання. Ще однією відмінною рисою даного дослідження $\epsilon$ використання нової технології побудови ТМ операторського класу - Carrier Ethernet (CE) [9]. В основі даної технології лежать механізми для контролю стану i управління мережевими елементами (механізми ОАМ). Побудова СУ такою мережею можлива 3 використанням результатів агентного способу моделювання, що дають можливість побудови моделей великого 
масштабу і складності, таких як телекомунікаційна мережа системи зв'язку ЗС України. Як об'єкт управління в роботі розглядається мережа СЕ. Мережа зв'язку має визначену структуру, що складається 3 окремих елементів. Під елементом розуміється вузол і канал передачі інформації. В якості вузлів в такій мережі може виступати комплекс спеціального обладнання (маршрутизатори, комутатори, мультиплексори та ін.), яке забезпечує передачу різного роду інформації і зв'язність мережі. Завданням мережі зв'язку є виконання функцій надання та підтримки послуг зв’язку з заданими параметрами.

Для виявлення взаємозалежності між показниками надійності функціонування мережі і процесом функціонування підсистем управління i відновлення ТМ необхідно отримати значення параметрів, які характеризують надійність мережі. Даними параметрами являються тривалість часу напрацювання на відмову та тривалість відновлення відмов. Для визначення даних параметрів необхідно вирішити задачу, пов'язану 3 розробкою моделі функціонування ТМ в складі мультиагентної системи управління (МАСУ), яка в свою чергу формалізує функції механізмів ОАМ. Відповідно до функціональної моделі МАСУ [10] збір і реєстрація даних для реалізації механізмів ОАМ здійснюється агентами реєстрації та аналізу подій. Тому при моделюванні МАСУ ТМ під агентом МАСУ будемо розуміти агент реєстрації та аналізу подій, який в свою чергу відображає стан і параметричний простір деякого елементу ТМ. Кожен агент МАСУ містить інформацію про елемент ТМ. Для створення моделі МАСУ використовувалось середовище моделювання AnyLogic, що відрізняється від інших різноманіттям способів оцінки результатів i можливістю використання агентного способу моделювання. Імітаційне моделювання AnyLogic дозволяє ефективно створювати мережі зв'язку різноманітної складності і проводити дослідження.

Аналіз останніх досліджень і публікацій. Загальні поняття ролі системи управління, iï взаємозв'язок $з$ телекомунікаційною мережею та 3 iii технічною експлуатацією отримало новий розвиток та наповнення в розробленій в рамках Міжнародного союзу електрозв'язку (MCE-T) концепції мережі управління електрозв'язком (TMN - Telecommunication management network). Послуги управління стандартизуються у рамках Рекомендацій МCE-T серії М [1-5]. В даних рекомендаціях визначені принципи організації TMN. Дана мережа є окремою мережею, яка має інтерфейси з однією або великою кількістю мереж зв'язку у декількох точках. TMN обмінюється 3 цими мережами інформацією i керує їх функціонуванням. Відділення мережі управління від мереж зв'язку реалізується на фізичному або логічному рівні. На логічному рівні TMN може частково використовувати інфраструктуру мережі над якою здійснюється управління. В Рекомендації М.3010 визначені принципи організації та області застосування, приведені функціональна та інформаційна архітектури, надані приклади фізичної архітектури та визначаються чотири основних набори блоків функцій. В Рекомендаціях M.3020 представлена методологія опису функціональних характеристик та специфікація інтерфейсів мережі (протоколів для інтерфейсів), М.3100 пропонує загальну інформаційну модель мережі, яка описує класи керованих об'єктів та їх властивості. М.3200 описує загальне використання TMN в різних телекомунікаційних мережах та послуги управління, М.3400 визначає функції управління керованими ресурсами телекомунікацій.

В монографії [6] розкриті системні проблеми та способи їх вирішення при організації управління сучасними телекомунікаційними мережами. Розглянуті основні положення по організації автоматизованого управління зв'язком, приводиться їх архітектура та основні задачі мережевого управління. Представлені моделі мереж зв'язку, приведені поняття, які визначають ефективність управління мережами та способи їх оцінки, методи та алгоритми рішення задач управління комутаційним обладнанням та телекомунікаційними мережами.

В виданні [7] надані основи інфокомунікацій, визначені загальні поняття про системи електрозв'язку та сигнали, докладно розглянуті мережі Next Generation Networks (NGN), їх базові принципи й структура, яка включає в себе способи комутації, що застосовуються в сучасних транспортних мережах, принципи комутації каналів, повідомлень і пакетів, мультисервісні мережі побудованих за концепцією NGN, принципам побудови глобальної мережі Інтернет та розкриває фундаментальні питання щодо системи управління інфокомунікаційними мережами.

В роботі [8] вказується, що сучасні транспортні телекомунікаційні мережі розвиваються, знаходяться на етапі модернізації, що полягає у переході від застарілих SDH та PDH технологій до нового покоління Carrier Ethernet. При цьому управління мережами зв'язку, що працюють на нових технологіях, неможливе без модернізації існуючої системи управління. Одним із шляхів модернізації $€$ застосування підсистеми моделювання та прогнозування процесів і стану телекомунікаційних мереж на основі апарату моделювання агентів. Методи дослідження засновані на фундаментальних концепціях теорії систем, управління, теорії ймовірностей, теорії побудови мультиагентних систем та теорії надійності. До експериментальних методів дослідження належать: метод математичної статистики, а також метод моделювання агентів.

В доповіді [9] модель інтелектуальної системи управління мережею Carrier Ethernet була розроблена для забезпечення своєчасної обробки значної кількості вхідної інформації в умовах погано формалізованих та погано структурованих завдань за відсутності повної та достовірної інформації про стан елементів мережі, а також 3 
обмеженим часом на прийняття рішень. Ця математична модель представлена у вигляді стохастичної мережі. Її топологічне перетворення методом двомоментного наближення дозволяє отримати функцію розподілу часу реалізації циклу управління 3 урахуванням впливу кожного підпроцесу. Для вирішення поставленої мети використовувались такі методи: підписні, статистичні та нейронні мережі. Результати досліджень можуть бути використані в існуючих та майбутніх комплексах систем діагностики стану мережі CE.

В статі [10] розглядаються поняття агента, мультиагентної системи, розглянуті основні види агентних архітектур, а також узагальнений підхід до побудови розподілених інтелектуальних інформаційних систем 3 використанням мультиагентних технологій.

Таким чином проведений аналіз основних публікацій та досліджень показав, що на сьогоднішній день існує безліч стандартів та робіт, де описані архітектура і механізми контролю та управління елементами мережі Carrier Ethernet, але не існує єдиної методики та не сформовані вимоги до системи управління такою мережею зв'язку.

Метою роботи $\epsilon$ виявлення залежності між показниками надійності функціонування телекомунікаційної мережі на основі технології Carrier Ethernet i процесом функціонування підсистем управління і відновлення телекомунікаційної мережі. А також отримання залежності коефіцієнту готовності від тривалості часу напрацювання на відмову, часу відновлення відмови та від кількісних характеристик конфігурації модельованого фрагмента мережі.

\section{Виклад основного матеріалу дослідження}

Розроблення єдиної методики та формування вимог до системи управління ТМ зв'язку пропонується шляхом моделювання процесу функціонування фрагменту ТМ ЗС України для управління іiї конфігурацією.

Процес розробки моделі включає в себе декілька етапів, які у вигляді окремих блоків представлені на рис. 1 .
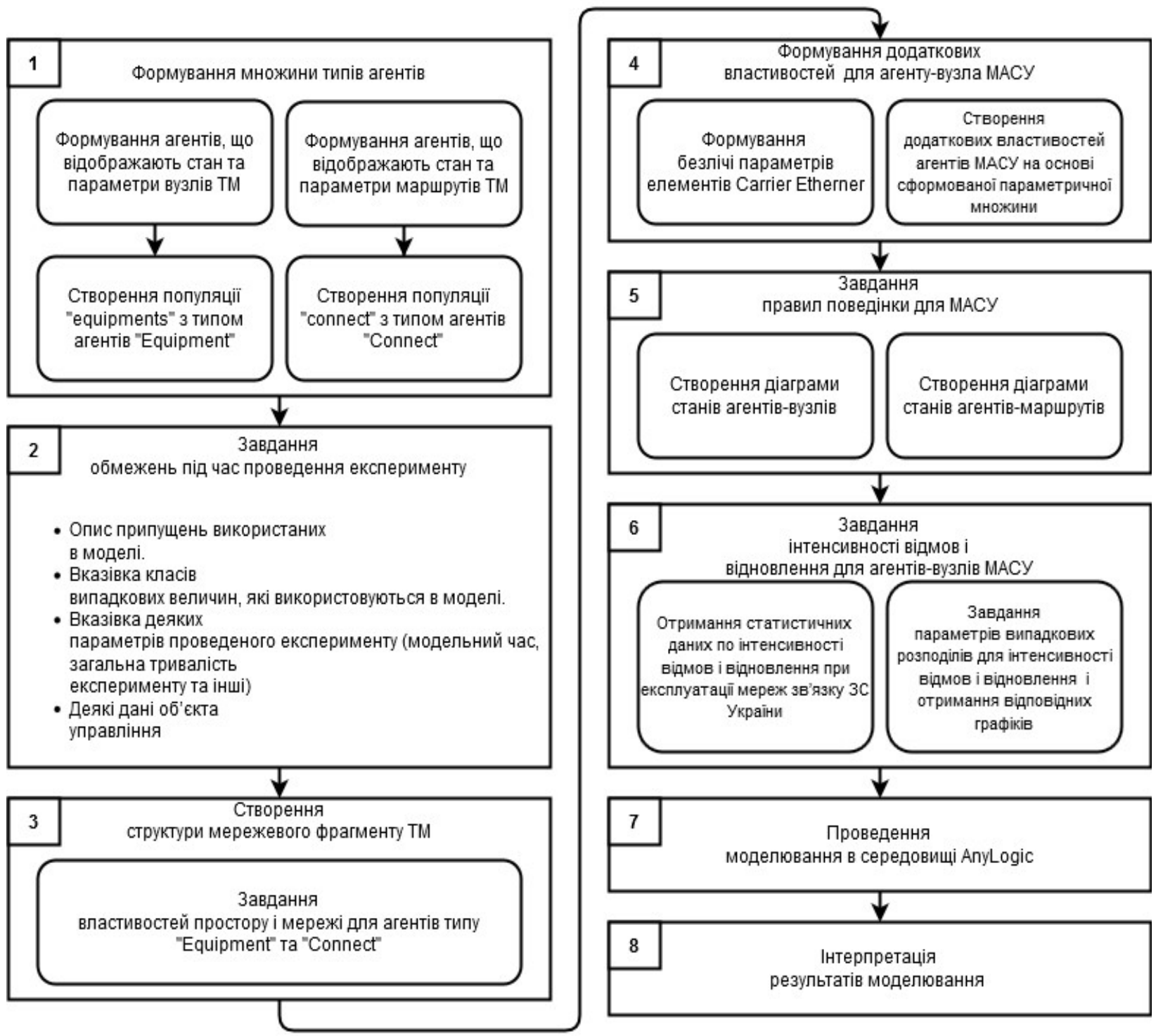

Рис. 1. Структура імітаційної моделі МАСУ 
Так як основними елементами ТМ є вузлові комутатори (маршрутизатори) та їх з'єднання, то елементи мережі в моделі функціонування можна класифікувати на елементи, до яких відносяться вузли ТМ, i маршрути, до яких відноситься сукупність деяких вузлів i каналів передачі інформації ТМ. При створенні моделі МАСУ передбачається створення таких агентів, які $\epsilon$ інформаційним відображенням кожного елемента TM. Модель функціонування описує фрагмент ТМ під керуванням одного вузла МАСУ. Передбачається, що в кожному фрагменті ТМ $є$ безліч вузлів $E$ i безліч маршрутів $C$, а у відповідному вузлі МАСУ $є$ безліч агентів-вузлів $A^{E}$ і безліч агентів-маршрутів $A^{C}$. Так як в середовищі AnyLogic при агентному способі моделювання модельованою одиницею $є$ агент, то поняття агента МАСУ як програмної реалізації елементу ТМ буде збігатися з поняття агенту моделі. Але якщо в першому випадку агентом $\epsilon$ структурний блок МАСУ [8], то агентом в моделі $є$ програмна реалізація вузла ТМ або маршруту, який з'єднує кілька вузлів.

В середовищі моделювання AnyLogic безліччю агентів одного і того ж типу називається популяція агентів. За таким принципом в моделі створені дві популяції: «еquipments» 3 типом агентів «Equipment» - для створення агентів-вузлів і «connect» 3 типом агентів «Connect» - для створення агентів-маршрутів (Блок 1 на рис. 1). В силу того, що до завдань вузла МАСУ відноситься управління фрагментом ТМ, то конфігурація фрагменту ТМ повинна бути задана для відповідного вузла МАСУ. У середовищі моделювання формується простір, в якому будуть існувати і взаємодіяти агенти (Блок 2 на рис. 1). Причому простір формується шляхом налаштувань мережі автоматично або вручну шляхом завдання статичних $\mathrm{i}$ динамічних координат місця розташування для кожного агента.

Всі елементи ТМ характеризуються набором параметрів. Зміна значень параметрів в результаті впливу на мережу різних факторів впливає на стан відповідних вузлів і маршрутів ТМ, і в цілому всього фрагмента ТМ. Дані зміни будуть відображати агенти МАСУ, а в кінцевому підсумку ця зміна буде впливати на формування нової конфігурації ТМ. В даній роботі зміна параметрів задавалася 3 допомогою функції випадкового розподілу для часу напрацювання на відмову і функції випадкового розподілу для часу відновлення відмови елементу ТМ. Модель передбачає наявність параметричного простору, зміна якого впливає на значення надійності ТМ. В [5] представлено безліч параметрів вузлів ТМ, які в МАСУ відображаються у вигляді безлічі атрибутів. В табл. 1 представлені параметри агентів МАСУ, які враховувалися в моделі як додаткові властивості у агентів моделі (Блок 3 на рис. 1).

Таблиця 1

Додаткові властивості агентів МАСУ

\begin{tabular}{|c|c|c|c|}
\hline $\begin{array}{c}\text { Класифікація } \\
\text { параметрів } \\
\text { в МАСУ }\end{array}$ & Назва параметру & Тип & Множина значень \\
\hline \multirow{17}{*}{$\begin{array}{c}\text { Параметри } \\
\text { конфігурації }\end{array}$} & \multirow{4}{*}{ Ethernet } & boolean & VLAN tunnelinq (Q-in-Q) for TLS \\
\hline & & boolean & IEEE 802.3u (Fast Ethernet) \\
\hline & & string & IEEE 802.3x,z,d,q,ad,ab,ah,s \\
\hline & & boolean & VLAN Translation \\
\hline & \multirow{3}{*}{$\begin{array}{c}\text { Захист } \\
\text { 3’єднання та } \\
\text { шляхи }\end{array}$} & boolean & Ручна агрегація з’єднань \\
\hline & & boolean & STP \\
\hline & & boolean & RSTP Self Loop Detection \\
\hline & \multirow{5}{*}{ Тип порту } & \multirow{5}{*}{$\begin{array}{l}\text { boolean \& } \\
\text { integer }\end{array}$} & 4 x 1000 BASE-FX ports \\
\hline & & & $16 \times 1000$ BASE-FX ports \\
\hline & & & $24 \times 1000$ BASE-FX ports \\
\hline & & & $1 \times$ OOB Management port \\
\hline & & & $1 \times$ Console Port (RS-232) \\
\hline & \multirow{5}{*}{$\begin{array}{l}\text { Управління } \\
\text { мережею }\end{array}$} & boolean & SNMP, SNMP MIB II (RFC 1213) \\
\hline & & boolean & Y.1731 Performance Monitoring \\
\hline & & boolean & IEEE 802.log \\
\hline & & boolean & Connectivity Fault Management \\
\hline & & boolean & $\begin{array}{c}\text { Fault Detection (Trace route, packet trace, } \\
\text { IFG shaving) }\end{array}$ \\
\hline \multirow{4}{*}{$\begin{array}{c}\text { Параметри } \\
\text { оцінки стану }\end{array}$} & \multirow{4}{*}{$\begin{array}{c}\text { Якість наданих } \\
\text { послуг }\end{array}$} & string & 128 рівнів сервісів \\
\hline & & integer & CIR \\
\hline & & integer & EIR \\
\hline & & string & DiffServ \\
\hline
\end{tabular}


Правила поведінки для агентів МАСУ, які враховують особливості архітектури ОАМ Carrier Ethernet базуються на розроблених алгоритмах управління [5]. Дані алгоритми включають в себе ряд підпроцесів 3 управління i контролю несправностями. Результати моделювання [5] цих підпроцесів використані в дослідженні даної роботи. В моделі у агентів враховуються ряд станів, що характеризують їх робочий стан (Блок 4 на рис. 1). Перехід агентів $з$ одного стану в інший задається за допомогою відповідних параметрів (Блок 5 на рис. 1):

1) Функція розподілу ймовірності відмови елементу ТМ задана за допомогою закону випадкового розподілу Вейбула-Гніденка:

$$
E(t)=1-e^{-(t / \sigma)^{b}}
$$

Даний розподіл було отримано на основі статистичних даних функціонування телекомунікаційного обладнання за результатами двох років його роботи, а також для отримання такого розподілу були розраховані його параметри [10].

$$
\begin{gathered}
\hat{b}=\frac{\ln \ln F_{2}-\ln \ln F_{1}}{\ln ^{t_{2}} / t_{1}} \\
\hat{a}=\frac{t_{1}}{\left(-\ln F_{1}\right)^{1 / b}}
\end{gathered}
$$

де $F_{1}$ i $F_{2}$ - точки емпіричної функції розподілу часу, a $\mathrm{t}_{1} \mathrm{i} \mathrm{t}_{2}$ - інтервали часу експлуатації обладнання, отримані в результаті побудови експериментальної функції розподілу відмов обладнання зв'язку різного типу.

2) Функція розподілу часу відновлення елементу ТМ задана за допомогою змінних AnyLogic, які дозволяють задавати цю величину як випадкову i формувати для неї нормальний розподіл з необхідними характеристиками.

Варто зазначити, що агенти в середині своєї популяції, а також між популяціями обмінюються керуючою інформацією, наприклад, повідомляючи агенту-маршруту про несправних агентів-вузлів, що входять в конфігурацію даного маршруту. Таким чином, в агентному середовищі стан елементів задається за допомогою функцій розподілу ймовірності і відновлення відмови, а стан маршрутів буде залежати від стану елементів, які входять в даний маршрут.

Зміна стану елементу ТМ відбивається в МАСУ шляхом зміни стану відповідного агенту вузла МАСУ. Після чого безпосередньо агент, а також інші блоки управління вузла МАСУ [10] реагують на зміни відповідно до алгоритму контролю стану і управління елементами ТМ. В даній моделі використовувався отриманий раніше алгоритм роботи процесів періодичного контролю і стану фрагмента ТМ [9].

При зміні стану будь-якого агента, запускається алгоритм контролю стану і управління елементами ТМ. Стан агента-вузла діагностується за допомогою повідомлення ССМ (Continuity Check Message). В результаті оцінки даних повідомлень ССМ для одного маршруту фрагмента мережі можливі два випадки:

1) Невідповідностей не виявлено, маршрут СПРАВНИЙ, вузли маршруту знаходяться в справному стані. В цьому випадку алгоритм запускає підпроцес перевірки параметрів елементів даного маршруту.

2) Виявлена НЕСПРАВНІСТЬ в маршруті. В цьому випадку маршрут встановлюється в несправний стан; запускається підпроцес локалізації несправності для пошуку несправного агента; далі запускаються підпроцеси відновлення агента і формування безлічі варіантів щодо зміни конфігурації фрагмента мережі.

При моделюванні приймаються обмеження i допущення (Блок 6 на рис. 1):

Розглядається фрагмент ТМ під керуванням одного вузла МАСУ.

1. Вузол МАСУ складається 320 агентів, які відображають стан відповідних вузлів ТМ;

2. Функції розподілу випадкових величин відносяться до класу нормальних і ВейбулаГніденка;

3. Характеристики випадкових величин визначаються статистичними способами;

4. Тривалість експерименту не перевищує 10 років модельного часу;

5. Середня кількість вузлів, що входять до складу маршруту складає 5.

На рис. 2 представлений прототип фрагменту TM, на основі якої проводилося моделювання функціонування.

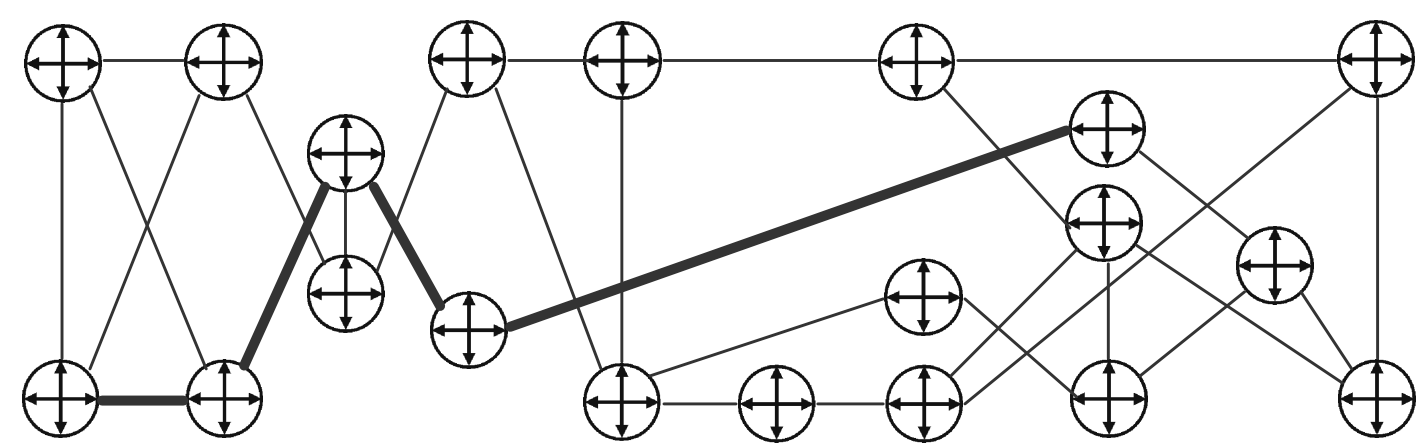

Рис. 2. Структура моделі фрагменту ТМ з наведенням прикладу маршруту 
В результаті моделювання були отримані значення величин часу напрацювання на відмову і часу відновлення для мармрутів фрагменту мережі, представленого на рис. 2. Дані значення отримуються в результаті моделювання в AnyLogic (програма безкоштовна) та представляються у вигляді великого масиву даних для кожної відмови кожного агента та часу напрацювання на відмову і часу його відновлення для вузлів фрагменту мереж, тому беруться середні значення відповідних величин.

Після визначення середнього часу напрацювання на відмову ( $\left.\mathrm{T}_{\text {чнв}}\right)$, середнього часу відновлення відмови $\left(\mathrm{T}_{\text {чвв }}\right)$ і коефіцієнта готовності TM $\left(\mathrm{K}_{\Gamma}\right)$ визначаються основні показники надійності.

По результатам моделювання отримуються два значення коефіцієнта готовності:

1) Для оцінки надійності фрагмента мережі, структурованого за маршрутами і використаними для управління несправностями алгоритми контролю стану і управління елементами ТМ на базі технології СЕ, отримується середнє значення коефіцієнта готовності мережі $\mathrm{K}_{\Gamma 1}$.

2) Для оцінки надійності фрагмента мережі

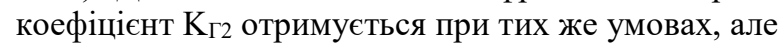
без урахування доменів технології СЕ, передбачених архітектурою ОАМ технології СЕ.

Це означає те, що крім механізмів контролю та управління станами мережевих елементів в значній мірі на значення надійності ТМ впливає архітектура ОАМ, яка визначає конфігурацію маршрутів ТМ.

Основним висновком за результатами моделювання $є$ те, що коефіuієнт готовності мережі $-K_{\Gamma}$ чутливий до ключових параметрів моделі - $\mathrm{k}$ (кількість вузлів в маршруті), L (кількість вузлів всередині фрагмента мережі), $\mathrm{T}_{\text {чнв }}$ (час напрацювання на відмову елемента CE), $\mathrm{T}_{\text {чвв }}$ (час відновлення відмови елемента СЕ).

Проведені дослідження [6] в області вирішення завдань, пов'язаних з оцінкою надійності мереж, були основою і передумовою представленого в даній роботі дослідження. Отримана модель дозволяе простежувати динаміку поведінки кожного вузла і кожної лінії зі своїми значеннями інтенсивності відмов і інтенсивності відновлення для конфігурації мережі високої складності таких як ТМ 3С України, а також дозволяє вирішувати завдання, пов'язані 3 визначенням тривалості часу до втрати зв'язності в маршруті і тривалості напрацювання на відмову всіх маршрутів одночасно. Це в свою чергу дозволяє формувати оцінку мережевої надійності i відмовостійкості. На підставі цього отримані значення коефіцієнта готовності для маршрутів i окремо взятих вузлів ТМ.

При оцінці отриманих значень виявлено те, що найбільше значення коефіцієнта готовності має мережа при наявності в ній маршрутів, які контрольовані і керовані за допомогою процесів на основі механізмів ОАМ. Незважаючи на те, що значення тривалості часу напрацювання на відмову для окремо взятого вузла ТМ набагато перевищує значення цього параметру для маршруту TM, можливість управління станом маршрутів 3 попереднім контролем стану вузлів, які входять до нього (рис. 2), дозволяє отримати найбільші значення коефіцієнта готовності $\mathrm{K}_{\Gamma}$.

Моделювання процесу функціонування ТМ дозволяє на етапі проектування перспективної системи управління ТМ на базі технології Carrier Ethernet вибирати той чи інший варіант формування конфігурації мережі СЕ.

Крім цього, за результатами моделювання виявлена чутливість моделі до таких параметрів як - кількість елементів в маршруті, кількість елементів у фрагменті мережі, час напрацювання на відмову у елементі СЕ, час відновлення відмови у елементі СЕ. Установлені за результатами моделювання закономірності залежності коефіцієнту готовності від цих параметрів можуть бути використані для вибору прийнятної кількості елементів у маршруті та в окремих сформованих фрагментах мережі, а також вибір оптимального рівня надійності мережі в залежності від необхідного значення коефіцієнту готовності.

\section{Висновки й перспективи подальших} досліджень

Розглянута система управління телекомунікаційної мережі на основі технології Carrier Ethernet забезпечить побудову моделей великого масштабу і складності, таких як ТМ системи зв'язку ЗС України. Застосоване імітаційне моделювання AnyLogic (програмний продукт $є$ в вільному доступі та постійно оновлюється) дозволить ефективно створювати мережі зв'язку різної складності і проводити 3 ними дослідження. Використання представленої моделі для дослідження функціонування ТМ дозволяє простежувати динаміку поведінки кожного вузла i кожного маршруту зі своїми значеннями інтенсивності відмов і відновлення для будь-яких мереж та вирішувати завдання, пов'язані з визначенням тривалості часу до втрати зв'язності в маршруті i тривалості часу напрацювання на відмову всіх маршрутів одночасно, а також формувати оцінку мережевої надійності та відмовостійкості.

В подальшому моделювання AnyLogic дозволить ефективно створювати імітаційне моделювання різних мереж зв'язку і проводити різноманітні дослідження. На етапі проектування мереж зв'язку імітаційне моделювання дозволить оцінити якість функціонування за показниками: коефіцієнт пропускної здатності мережі в цілому і коефіцієнти пропускної здатності абонентабонент, середній час передачі одного повідомлення, середній час затримки пакетів повідомлень, ймовірність втрат пакетів i повідомлень та інше. 


\begin{abstract}
Jimepamypa
1. ITU-T Recommendation M.3010 2000 Principles for a telecommunications management network (Рекомендації MCE-T М.3010 2000 Принципи роботи мережі телекомунікацій). 2. ITU-T Recommendation M.3020 2017 Management interface specification methodology (Рекомендації МСE-T М.3020 2017 Методологія специфікації інтерфейсу управління). 3. ITU-T Recommendation M.3100 2005 Generic network information model (Рекомендації MCE-T M.3100 2005 Загальна інформаційна модель мережі). 4. ITU-T Recommendation M.3200 1997 TMN management services and telecommunications managed areas: overview (Рекомендації МСЕ-Т М.3200 1997 Послуги управління TMN та керовані області телекомунікацій: огляд) 5. ITU-T Recommendation M.3400 $2000 \mathrm{TMN}$ management functions (Рекомендації MCE-T M.3400 2000 Функції управління TMN). 6. Буренин А.Н., Курносов В.И. Теоретические основы управления современными
\end{abstract}

телекоммуникационными сетями: / А.Н. Буренин, В.И. Курносов // - М.: Наука, 2011. - С. 18 - 20, С. 464. 7. Кривуца В.Г. Основи інфокомунікацій: / В.Г. Кривуца, Л.Н. Беркман, В.В. Лапінський // - К.: ДУІКТ, 2011. - С. 218 - 235. 8. Котенко И.В. Теория управления в системах военного назначения. Учебник / А.В. Боговик , С.С. Загорулько , И.С. Ковалев , И.В. Котенко , В.В. Масановец // - М.: МО, 2001. - С. 1-320. 9. Бенета Э В., Канаев А.К., Сахарова М.А., Комплексная математическая модель процесса функционирования интеллектуальной системы управления сетью Carrier Ethernet / Э.В. Бенета, А.К. Канаев, М.А. Сахарова, // - СПб.: СПбГЭУТ «ЛЭТИ», 2017. Т. 1. - С. 282 -285. 10. Ландсберг С.Е. Особенности построения информационных систем с использованием мультиагентных технологий / C.Е. Ландсберг, А.А. Хованских // - В.: Журнал Вестник, ВГТУ 2014.

\title{
ПРИМЕНЕНИЕ МУЛЬТИАГЕНТНОЙ СИСТЕМЫ УПРАВЛЕНИЯ МОДЕЛИ ФУНКЦИОНИРОВАНИЯ ФРАГМЕНТА ТЕЛЕКОММУНИКАЦИОННОЙ СЕТИ СИСТЕМИ СВЯЗИ ВООРУЖЕННЫХ СИЛ УКРАИНЫ
}

\author{
Владимир Иванович Руденко \\ Михаил Александрович Зинченко \\ Наталья Сергеевна Гришина \\ Виктор Анатольевич Ченченко
}

\section{Военный институт телекоммуникаций и информатизации имени Героев Крут, Киев, Украина}

На сегодняшний день сущуествует множество стандартов, где описань архитектура и механизмы контроля и управления элементами сети Carrier Ethernet, но не существует единой методики и не сформированы требования к системе управления такой сетью связи. В данной статье предложено решение этой задачи путем моделирования прочесса функционирования телекоммуникационной сети на основе данной технологии для управления ее конфигураџией. Для создания данной модели выбран аппарат имитаџионного моделирования AnyLogic. Целью работь является выявление зависимости между показателями надежности функционирования телекоммуникационной сети на основе технологии Carrier Ethernet и процессом функционирования подсистем управления и восстановления телекоммуникационной сети. А также получение зависимости коэффициента готовности от продолжстельности времени наработки на отказ, времени отказа и от количественных характеристик конфигурации моделируемого фрагмента сети. Мультиагентная система, которая является частью управляющей системы, находится во взаимодействии с ней. Использование в мультиагентной системе управления распределенного объекта управления телекоммуникационной сети на основе технологии Carrier Ethernet позволит получить демонстрацию динамики изменения состояния фрагмента телекоммуникаџионной сети и получить оценку сетевой надежности. Решение задачи по построению модели мультиагентной системы управления основывается на использовании метода агентного моделирования, который относится к классу агенториентированных моделей. B работе используются положения теории вероятностей, теории управления и теории систем. Новизна представленной модели заключается в выборе нового объекта управления Carrier Ethernet, выборе оригинального комплекса механизмов контроля и управления для их включения в модель, применении математического аппарата агентного моделирования. Использование представленной модели для исследования функиионирования телекоммуникационной сети позволяет прослеживать динамику поведения каждого узла и каждого марирута со своими значениями интенсивности отказов и восстановления для структуры сети любой сложности, позволяет решать задачи, связанные с определением продолжительности времени к потере связности в маршруте и продолжительности времени наработки на отказ всех маршрутов одновременно, позволяет формировать оценку сетевой надежности и отказоустойчивости.

Ключевые слова: телекоммуникационная сеть связи; Carrier Ethernet; Агентное моделирование; AnyLogic; система управления; сетевая надежность. 


\title{
APPLICATION OF THE MULTI-AGENT CONTROL SYSTEM OF THE MODEL OF FUNCTIONING OF THE TELECOMMUNICATION NETWORK FRAGMENT BY COMMUNICATION SYSTEMS OF THE ARMED FORCES OF UKRAINE
}

\author{
Volodymyr Rudenko \\ Mykhailo Zinchenko \\ Natalia Gryshina \\ Viktor Chenchenko
}

\section{Military Institute of Telecommunications and Informatization named after Heroes Krut, Kiev, Ukraine}

Today, there are many standards that describe the architecture and mechanisms for monitoring and controlling elements of the Carrier Ethernet network, but there is no single methodology and requirements for the control system of such a communication network are not formed. This article proposes a solution to this problem by modeling the process of functioning of a telecommunication network based on this technology to manage its configuration. To create this model, the AnyLogic simulator was selected. The aim of the work is to identify the relationship between the reliability indicators of a telecommunication network based on Carrier Ethernet technology and the process of functioning of the telecommunication network management and recovery subsystems. As well as obtaining the dependence of the availability factor on the duration of the time between failures, the time of failure and on the quantitative characteristics of the configuration of the simulated network fragment. The multi-agent system, which is part of the control system, is in interaction with it. The use of a distributed telecommunications network control facility based on Carrier Ethernet technology at MASU will provide a demonstration of the dynamics of changes in the state of a fragment of a telecommunications network and obtain an estimate of network reliability. The solution to the problem of building the MASU model is based on the use of agent-based modeling, which belongs to the class of agent-based models. The paper uses the provisions of probability theory, control theory and system theory. The novelty of the presented model lies in the selection of a new Carrier Ethernet control object, the selection of an original set of control and management mechanisms for their inclusion in the model, and the use of the mathematical apparatus of agent modeling. Using the presented model to study the functioning of a telecommunication network allows you to track the behavior of each node and each route with its own failure and recovery rates for a network structure of any complexity, and allows you to solve problems associated with determining the length of time to lose connectivity in the route and the duration of the time between failures all routes simultaneously, allows you to form an assessment of network reliability and fault tolerance.

Key words: telecommunication communication network; Carrier Ethernet; Agent based modeling; AnyLogic; control system; network reliability.

\section{References}

1. ITU-T Recommendation M.3010 2000 Principles for a telecommunications management network (Rekomendatsii MSE-T M.3010 2000 Pryntsypy roboty merezhi telekomunikatsii). 2. ITU-T Recommendation M.3020 2017 Management interface specification methodology (Rekomendatsii MSE-T M.3020 2017 Metodolohiia spetsyfikatsii interfeisu upravlinnia). 3. ITU-T Recommendation M.3100 2005 Generic network information model (Rekomendatsii MSE-T M.3100 2005 Zahalna informatsiina model merezhi). 4. ITU-T Recommendation M.3200 1997 TMN management services and telecommunications managed areas: overview (Rekomendatsii MSE-T M.3200 1997 Posluhy upravlinnia TMN ta kerovani oblasti telekomunikatsii: ohliad). 5. ITU-T Recommendation M.3400 2000 TMN management functions (Rekomendatsii MSE-T M.3400 2000 Funktsii upravlinnia TMN). 6. Burenin A.N., Kurnosov V.I.
Teoreticheskie osnovyi upravleniya sovremennyimi telekommunikatsionnyimi setyami: / A.N. Burenin, V.I. Kurnosov // - M.: Nauka, 2011. - S. 18 - 20, S. 464. 7. Kryvutsa V.H. Osnovy infokomunikatsii: / V.H. Kryvutsa, L.N. Berkman, V.V. Lapinskyi // - K.: DUIKT, 2011. - S. 218 - 235. 8. Kotenko I.V. Teoriya upravleniya v sistemah voennogo naznacheniya. Uchebnik / A.V. Bogovik, S.S. Zagorulko, I.S. Kovalev, I.V. Kotenko, V.V. Masanovets // - M.: MO, 2001. - S. 1-320. 9. Beneta E V., Kanaev A.K., Saharova M.A., Kompleksnaya matematicheskaya model protsessa funktsionirovaniya intellektualnoy sistemyi upravleniya setyu Carrier Ethernet / E.V. Beneta, A.K. Kanaev, M.A. Saharova, // - SPb.: SPbGEUT «LETI», 2017. T. 1. - S. 282 -285. 10. Landsberg S.E. Osobennosti postroeniya informatsionnyih sistem $\mathrm{s}$ ispolzovaniem multiagentnyih tehnologiy / S.E. Landsberg, A.A. Hovanskih // - V.: Zhurnal Vestnik, VGTU 2014. 